\title{
What is better: cryocautery or electrocautery for cervical erosion?
}

\author{
Monika Jindal*, Satwant Kaur, Sakshi Sharma, \\ Kumud Bala Gupta, Poonam Pandotra, Bhavna
}

\begin{abstract}
Department of Obstetrics \& Gynecology, Maharishi Markandeshwar Medical College \& Hospital, Solan, Himachal Pradesh, India
\end{abstract}

Received: 5 August 2014

Accepted: 19 August 2014

\author{
*Correspondence: \\ Dr. Monika Jindal, \\ E-mail: monikajindal@ @ocketmail.com
}

(C) 2014 Jindal $\mathrm{M}$ et al. This is an open-access article distributed under the terms of the Creative Commons Attribution Non-Commercial License, which permits unrestricted non-commercial use, distribution, and reproduction in any medium, provided the original work is properly cited.

\begin{abstract}
Background: Present study was conducted with a background in mind to compare the efficacy of electrocautery and cryocautery for the management of cervical erosion. Aim of this study was to compare the efficacy of electrocautery and cryocautery for the treatment of cervical erosion and to check cost effectiveness.

Methods: A comparative study was conducted at Maharishi Markandeshwar medical college and hospital, Kumarhatti (Solan) between July'13 to June'14 among 100 patients of reproductive age group with cervical erosion. They were grouped into 2 groups A (Electrocautery) \& B (Cryocautery) and data obtained was analysed by paired ttest.

Results: Though in short- term follow-up at 4-6 weeks after cautery, apparently electrocautery was superior to cryocautery in terms of erosion healing rate $92 \%$ vs. $76 \%$ as $\mathrm{P}$ value $(0.4557)$ is not statistically significant, but in long-term follow-up at 12-14 weeks there was no significant difference in erosion healing but electrocautery was cost effective.

Conclusions: Both types of cautery were equally good for treatment of cervical erosion in long-term follow-up. But electrocautery occupies less space and there is no chance of gas leakage in electrocautery, so electrocautery is more cost effective.
\end{abstract}

Keywords: Electrocautery, Cryocautery, Erosion, Discharge per vaginum, Eschar

\section{INTRODUCTION}

Non-communicable disease are emerging as important health problems with changes in lifestyles and demographic profiles of developing countries which demand an appropriate control program before they assume epidemic proportions.

Cervical erosion is one of the commonest gynaecological conditions seen in OPD's. About 85\% women suffer from cervical erosion. ${ }^{1}$ A benign lesion is sometimes much troublesome due to its chronicity and nature of recurrence. Cervical erosion is the replacement of nonkeratinised stratified squamous epithelium of portiovaginalis by columnar epithelium of endocervix., ${ }^{2,3}$
Though it is not fatal, yet the long term association with the disease and a number of symptoms both related to genitourinary system as well as psychological imbalance in the patient, needs attention.

Cervical erosion may be a cause of many gynaecological symptoms like discharge, backache, dyspaurenia, intermenstrual bleeding and bladder irritability etc. It can show malignant changes in chronic stage.

For treatment of cervical erosion we can do either the cryocautery or electrocautery. Cautery is an office procedure that usually can be performed without anaesthesia or analgesia. 
Cryosurgical instruments use either nitrous oxide (freezing point of $-89^{\circ} \mathrm{C}$ ) or carbon- dioxide $\left(\mathrm{CO}_{2}\right)$ (freezing point of $-65^{\circ} \mathrm{C}$ ) as refrigerant. Refrigerant lowers the temperature of tissue to $22^{\circ} \mathrm{C}$ in 3 minutes and produces cell death by intracellular or extracellular water crystallization. ${ }^{4}$ Ice-ball is allowed to enlarge until reaching a mark $7 \mathrm{~mm}$ distal to the probe margin. This ensures creation of freezing depth of $7 \mathrm{~mm}$. That includes $5 \mathrm{~mm}$ lethal zone and $2 \mathrm{~mm}$ zone of indeterminate tissue death. ${ }^{5}$ Patients treated with cryotherapy may experience cramping pain during procedure and profuse watery discharge after that. Some patients may experience spotting after 12-15 days of cautery due to fall of eschar.

Electrocautery is transfer of energy by heat, such as hot wire, electrons do not move into the affected tissue only heat is transferred and temperature ranges between 45 to more than 500 degree centigrade. ${ }^{6}$

Cautery is best performed when patient is not menstruating.

\section{METHODS}

This prospective study was conducted on 100 patients attending the out-patient department of MMMC\&H, Kumarhatti, Solan from June 2013 to May 2014 after taking permission from college ethical committee. Patients were divided into two groups - fifty in each group. Group A treated by electrocautery and Group B by cryocautery. Study was done according to preset proforma.

At first visit pelvic examination was done, Pap smear taken and single course of antibiotics was given to both the groups.

Cautery was done 2-3 days after cessation of menstruation. Pressure in the tank kept was $40 \mathrm{~kg} / \mathrm{cm}^{2}$ for cryocautery and time for freezing was 3 minutes. Electrocautery was done at medium current. Intra operative discomfort, pain and bleeding noted. Immediate post-operative discomfort, pain and bleeding also noted. Patients were followed up 3-4 days after cessation of menstruation at 4-6 weeks and 12-14 weeks. In both the groups, improvement in symptoms and erosion noted and thus data obtained was analysed by paired t-test.

\section{Inclusion criteria}

Female of reproductive age group

Only inflammatory changes in pap smear

\section{Exclusion criteria}

Pap smear with premalignant or malignant changes

Patient with high risk for cautery like heart disease or patient with metallic implants
Patients with pregnancy or menstruating

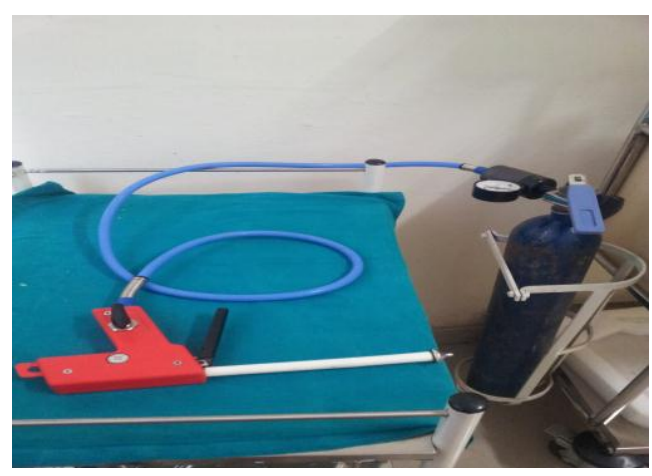

Figure 1: Cryocautery unit.

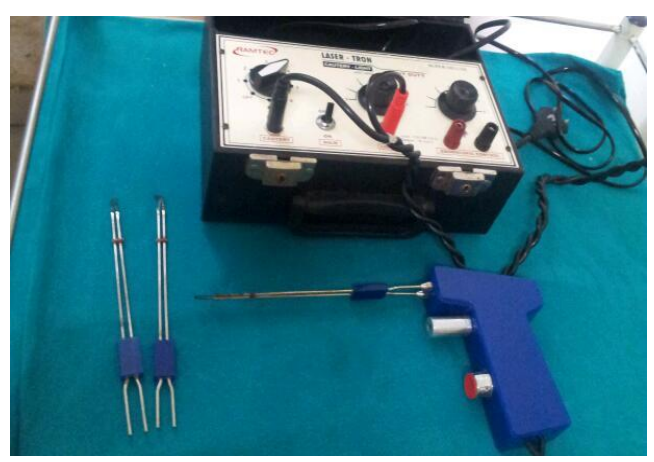

Figure 2: Electrocautery unit.

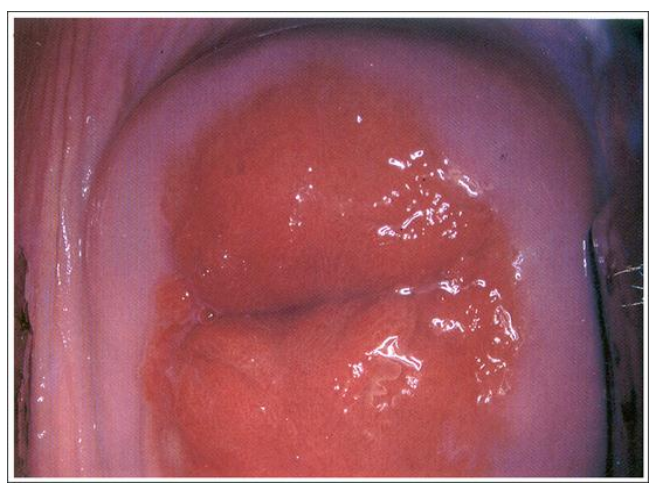

Figure 3: Cervical erosion before treatment.

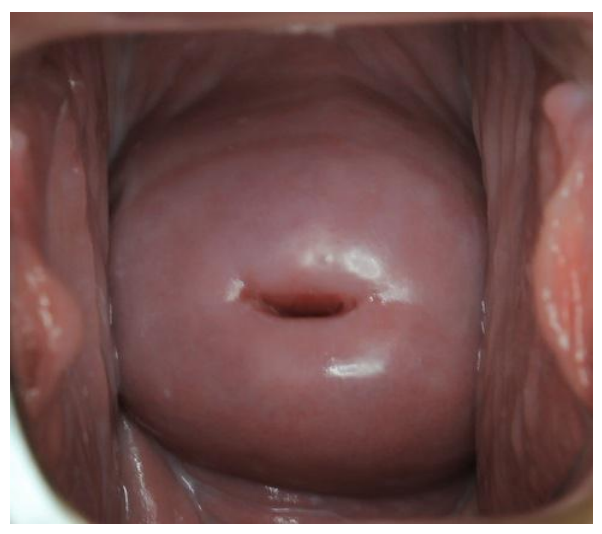

Figure 4: Cervix at follow up (12 weeks) of treatment. 


\section{RESULTS}

Distribution as per sample size shown as follow:

Table 1: Incidence of age, gravidity, parity and contraception usage in both the groups.

\begin{tabular}{|lll|}
\hline Variables & $\begin{array}{l}\text { Group A } \\
\text { (Electrocautery) }\end{array}$ & $\begin{array}{l}\text { Group B } \\
\text { (Cryocautery) }\end{array}$ \\
\hline Age (years) \& its mean & $\begin{array}{l}\text { 25-46 years } \\
\text { (31.32 years) }\end{array}$ & $\begin{array}{l}\text { 22-41 years } \\
(33.7 \text { years) }\end{array}$ \\
\hline Gravidity \& its mean & $2-6(2.9)$ & $2-5(2.6)$ \\
\hline Parity \& its mean & $2-6(2.5)$ & $2-5(2.2)$ \\
\hline Contraception & $42^{*}$ & $44 * *$ \\
\hline
\end{tabular}

*Only one patient in electrocautery group used oral contraceptive pills (Femilon), no patient in cryocautery group used OCP's.

**Maximum patients in both the groups were either tubectomized or used barrier method.

Table 2: Symptoms distribution before treatment.

\begin{tabular}{|lll|}
\hline Symptoms & Group A & Group B**** \\
\hline Discharge & 18 & 06 \\
\hline Pelvic pain & 03 & 03 \\
\hline Dyspaurenia & 01 & 01 \\
\hline Menstrual complaints* & 02 & 01 \\
\hline Backache & 00 & 00 \\
\hline Burning micturition & 04 & 01 \\
\hline Multiple complaints** & 22 & 38 \\
\hline
\end{tabular}

*Menstural complaints included dysmenorrhoea, irregular menses, postcoital and intermenstural spotting and oligomenorrhoea.

**Most patients with multiple complaints presented with discharge per vaginum, pelvic pain and lower backache.

***One patient in cryocautery group was diabetic.

Table 3: Intraoperative complaints.

\begin{tabular}{|lll|}
\hline Complaints & Group (A) & Group (B) \\
\hline Pelvic pain & $04(8 \%)$ & $04(8 \%)$ \\
\hline Backache & 00 & 00 \\
\hline Apprehension/discomfort & $08(16 \%)$ & $04(8 \%)$ \\
\hline Bleeding & $01(2 \%)^{*}$ & 00 \\
\hline
\end{tabular}

$P$ value 0.4226 not significant

*One patient in electrocautery group had bleeding. Pelvic pain incidence was similar in both the groups while discomfort was more during electrocautery.
Table 4: Immediate postoperative complaints.

\begin{tabular}{|lll|}
\hline Complaints & Group (A) & Group (B) \\
\hline Pelvic pain & 00 & $02(4 \%)^{*}$ \\
\hline Discomfort & $01(2 \%)$ & 00 \\
\hline Bleeding & 00 & 00 \\
\hline
\end{tabular}

$P$ value 0.7952 not significant

*Postoperative pelvic pain, backache and headache were observed in two patients treated with cryocautery.

Only one patient treated with electrocautery had discomfort.

Table 5: Symptoms and erosion remained after treatment at 4-6 weeks.

\begin{tabular}{|lll|}
\hline Symptom & Group (A) & Group (B) \\
\hline Discharge & 00 & $04(8 \%)$ \\
\hline Pelvic pain & 00 & 00 \\
\hline Intermenstrual spotting & $02(4 \%)$ & 00 \\
\hline Backache & $02(4 \%)$ & 00 \\
\hline Burning micturition & 00 & 00 \\
\hline Erosion & $04(8 \%)$ & $12(24 \%)$ \\
\hline
\end{tabular}

$P$ value 0.4557 not significant

There was spotting in two patients treated with electrocautery group. Thin watery discharge was observed in four patients treated with cryocautery. Backache was seen in two patients of electrocautery group. Residual erosion was there in four patients in electrocautery group and twelve patients treated with cryocautery. Patients were not given any treatment but asked for follow-up after twelve weeks.

Symptom cure rate was almost $100 \%$ at the end of twelve weeks in both the groups.

Residual erosion was present in one patient treated with cryocautery and repeat cautery was done.

\section{DISCUSSION}

Cervical erosion is commonly found in reproductive age group. Mean age in group (A) \& (B) was 31.32 \& 33.7 years respectively. There was no significant difference in age distribution in the two groups.

Mean gravida and para status in group (A) \& (B) was respectively $(2.9 \& 2.5),(2.6 \& 2.2)$. That means repeated pregnancies result in trauma to cervix leading to erosion. Gravida and para status in both the groups was almost similar.

Eighty four percent patients in group (A) \& 88\% patients in group (B) used contraceptive method and maximum patients were tubectomized. Others used barrier method 
and only one patient of group (A) used oral contraceptive pills (Femilon).

Maximum patients (44\%) in group (A) \& $76 \%$ in group (B) presented with multiple complaints that included discharge per vaginum, pelvic pain \& sore back. Other complaints were dyspareunia, burning micturition \& menstruation complaints.

Menstruation related complaints were dysmenorrhoea, irregular cycles, oligomenorrhoea, postcoital and intermenstural bleeding.

One patient of group (B) was diabetic.

During the procedure both groups had similar incidence of pelvic pain (8\%) \& backache (0) while discomfort/apprehension was more common in group (A) $16 \%$ as compared to group (B) $8 \%$ that is similar to Chia Koo Lee. ${ }^{7}$

Bleeding was seen in one patient treated with electrocautery that was controlled with vaginal packing. Difference of intraoperative complaints ( $\mathrm{P}$ value 0.4226 ) was not statistically significant.

Postoperatively pelvic pain remained in $4 \%$ cases in group (B) and discomfort in $2 \%$ in group (A). In 2 patients of group (B) there was headache and backache along with pelvic pain. Incidence of post-operative complaints ( $\mathrm{P}$ value 0.7952) were not statistically significant in both the groups. Headache may be due to more electrolyte loss in cryocautery that was relieved by taking fruit juice and high protein diet.

Self -limiting cramping pain, profuse vaginal discharge for 2-3 weeks ${ }^{8}$ can be seen in patients treated with cryocautery. In our study $8 \%$ patients had profuse vaginal discharge in group (B).

Spotting can also occur in patients treated with cautery. In our study intermenstural spotting took place in 2 patients of group (A) due to fall of eschar formation.

Area epithelises and heals in about 6 weeks. ${ }^{9}$ In our study at $\mathrm{I}^{\text {st }}$ follow-up between 4-6 weeks residual erosion was present in $8 \%$ \& $24 \%$ in group (A) \& (B) respectively. $\mathrm{P}$ value $(0.4557)$ was not significant.

Burning micturition may be due to associated vaginitis that got relieved with treatment. Symptom cure rate was almost $100 \%$ in both groups in long term follow up at 12 14 weeks. This was comparable to Miller et al. ${ }^{10}$ They didn't find much of difference between both groups.

Chia Koon Lee et al. ${ }^{7}$ found cryosurgery healing rate $(90 \%)$ better than electrocautery $(74.2 \%)$ but in our study in long term follow up healing rates were same in both groups. Only one patient in cryocautery group required repeat treatment and that patient was diabetic.

\section{CONCLUSION}

Though in short term follow up electrocautry seems to be better than cryocautry. But if seen in long term follow up both are equally good. Though I will favour electrocautry in terms of space occupancy, ease and cost effectiveness. No chance of leakage in electrocautry though sometimes vaginal or vulval burns may occur due to negligence but that is avoidable.

\section{Funding: No funding sources}

Conflict of interest: None declared

Ethical approval: The study was approved by the institutional ethics committee

\section{REFERENCES}

1. Neelam, Kumar N. Management of cervical erosion. Ayu. 2009 Apr-Jun;30(2):171-4.

2. John A. Rock. Principles of anatomy and perioperative considerations, surgical anatomy of female pelvis. In: John A. Rock, Howard W. Jones III, eds. Te Linde`s Operative Gynecology. 10th ed. Philadelphia: Wolters Kluwer/Lippincott Williams \& Wilkins; 2008: 82-112.

3. D. C. Dutta. Benign lesions of the cervix In: Hiralal Konar, eds. D. C. Dutta's Text Book of Gynaecology. 6th ed. Kolkata: New Central Book Agency (P) Ltd.; 2014: 254-258.

4. Narendra Malhotra, Pratap Kumar, Jaideep Malhotra, Neharika M. Bora, Parul Mittal. Epithelial Abnormalities of the Genital Tract. In: Narendra Malhotra, Pratap Kumar, Jaideep Malhotra, Neharika M. Bora, Parul Mittal, eds. Jeffcoate's Principles of Gynecology. 8th ed. New Delhi: Jaypee Brothers Medical Publishers (P) Ltd; 2014: 375-397.

5. Barbara L. Hoffman, Joha O. Schorge, Joseph I. Schaffe, Lisa M. Halvorson, Karan D. Bradshaw, F. Gary Cunnigham. Treatment of pre-invasive ectocervical lesions. In: Barbara L. Hoffman, Joha O. Schorge, Joseph I. Schaffe, Lisa M. Halvorson, Karan D. Bradshaw, F. Gary Cunnigham, eds. William's Gynecology. 2nd ed. New York: McGrawHill Books; 2012: 1078-1082.

6. John A. Rock. Principles of gynecologic surgical techniques and management of endoscopy. Principles of electrosurgery as applied to gynecology. In: John A. Rock, Howard W. Jones III, eds. Te Linde's Operative Gynecology. 10th ed. Philadelphia: Wolters Kluwer/Lippincott Williams \& Wilkins; 2008: 280-297.

7. Lee CK. Comparative and electro-cauterization in treatment of cervical erosion $\mathrm{J}$ Med Sci. 1977;2(2):519-34.

8. Sudha Salhan. Minor procedures. In: Sudha Salhan, eds. Textbook of Gynecology. 1st ed. New Delhi: Jaypee Brothers Medical Publishers (P) Ltd; 2012: 512-536.

9. V. G. Padubidri. Inflammation of uterus and cervix. In: V. G. Padubidri, eds. Hawkins \& Bourne Shaw's 
Textbook of Gynecology 15th ed. India: Elsevier - A Division of Reed Elsevier India Private Ltd; 2010: 323-329.

10. Miller JF, Elstein M. A comparison of electrocautery and cryocautery for the treatment of cervical erosions and chronic cervicitis. J Obstet Gynecol Br Common Wealth. 1973;80:658.

DOI: $10.5455 / 2320-1770 . \mathrm{ijrcog} 20140973$

Cite this article as: Jindal M, Kaur S, Sharma S, Gupta $\mathrm{KB}$, Pandotra P, Bhavna. What is better: cryocautery or electrocautery for cervical erosion? Int J Reprod Contracept Obstet Gynecol 2014;3:715-9. 